\title{
FDI Directed to Thailand by Chinese Enterprises for Circumlocutory Export
}

\author{
Kenji Nozaki (Corresponding author) \\ Faculty of Economics, Takasaki City University of Economics \\ 1300 Kaminamiemachi, Takasaki, Gunma, 3700801, Japan \\ Tel: 81-27-343-5417, E-mail: knozaki.kenji@gmail.com \\ Jingwei Shu \\ Faculty of Economics and Management, Surugadai University \\ 698 Azu, Hanno, Saitama 3578555, Japan
}

Received: April 15, 2017 Accepted: May 10, 2017 Published: May 22, 2017

doi:10.5296/jad.v3i2.11116 URL: https://doi.org/10.5296/jad.v3i2.11116

\begin{abstract}
The authors have conducted a survey to clarify FDI by Chinese enterprises in Thailand. The aim of our research is to verify the hypothesis that avoiding trade friction is an important determinant of China's outward FDI, through detailed investigation of individual project. Another aim is to confirm the trends of exports of the items involved from both China and Thailand. We discuss the role of FDI investment in relation to the behavior of the enterprises involved. Literatures indicate that multiple factors influence FDI, including trade barriers. We analyzed individual investment data from the BOI of Thailand. We found that, during 2007 to 2014, 94 projects out of a total of 240 intended to produce items which caused trade friction when exported from China. In fact, 12 of these 94 projects announced that they invested in Thailand to avoid trade frictions. Based on these results, we conclude that a substantial portion of China's outward FDI in Thailand is to prevent trade friction by aiming to export from Thailand. Exports of such goods from China continue to increase, whereas exports from Thailand are stagnant. A plausible explanation is that these investments were conducted by less competitive enterprises in China.
\end{abstract}

Keywords: China's outward FDI, anti-dumping, trade friction 


\section{Introduction}

Since economic reform began in 1978, China has promoted its exports mainly by accepting foreign direct investment (FDI). FDI has led to a current account surplus through increase of export and increased foreign reserves. In the 21 st century China has become an investing country, although FDI inflow remains large. As the increasing of China's outward investment influences the world economy, it is important to verify the reasons of China's FDI. At the same time, the increase of exports has caused trade friction against the United States and Europe. Trade friction may have influenced the investment behavior of China. Previous literatures have discussed the determinants of FDI. They have considered many aspects of situation of both investing countries and invested destinations. After increase of Japan's outward FDI, followed by other Asian nations, the analysis considering the situation of trade friction increased. In this paper, among the various reasons to invest outward, the present work is concerned with the avoidance of trade friction. This does not mean FDI to a trading counterpart, but FDI to a third country in order to export from that country.

Below, Chinese outward FDI to Thailand is surveyed. The background to this work is the existence of a Chinese plant area in an industrial park in Thailand. This is located close to Laemchabang Port, which is an export base in Thailand. It can be related with exports from Thailand by Chinese enterprises. The authors were interested in why the Chinese sited this park in Thailand, because the wages of Thai labor were as high as Chinese labor and the market of Thailand was not as large. We suspected that trade friction with developed countries caused Chinese enterprises to operate in Thailand in order to export their products from there.

We study the hypothesis that avoiding trade friction is an important determinant of China's outward FDI, via a detailed investigation of investment projects. A further purpose is to verify the export trends of the items manufactured from both China and Thailand. We discuss the role of investment in relation to the behavior of the enterprises involved.

The structure of this paper is as follows. In the next section we review the literature concerning FDI theory and empirical studies of FDI determinants. The macroeconomic background to the increase in China's outward FDI is discussed in section 3, and an overview of China's outward FDI to the ASEAN region in general and Thailand in particular is given in section 4. In section 5, taking into account market openness and the good relationship of developed countries with Thailand, we aim to clarify whether a substantial amount of China's outward FDI is intended to produces items facing trade friction when exported from China. The exports of these items from Thailand and from China is surveyed in section 6 . Conclusions and the direction of future studies are set out in section 7 .

\section{Literature Review}

The factors determining FDI have been discussed for many years. They can be broadly classified into three categories: (a) difference in capital endowment; (b) monopolistic/oligopolistic advantages of multi-national enterprises (MNEs); and (c) movement of business resources. The notion of difference in capital endowment derived from 
MacDougall (1960), the idea of monopolistic/oligopolistic advantages of MNEs from Hymer (1960) and Kindleberger (1969), and the idea of movement of business resources from Komiya and Amano (1972).

Empirical studies have sought to specify a group of relevant FDIs. Case studies were first conducted in US MNEs in the 1980's, by Grubert and Mutti (1991) and Wheeler and Mody (1992), among others. They analyzed the effects of taxation policies and FDI policies. Empirical studies of Japanese FDIs followed in the mid to late 1990s. This brings to mind the large trade surplus, especially with the US, and many plants being outsourced to developed countries and to developing Asian regions. There have been various case studies; in particular, Fukao and Cheng (1996) studied empirically the determinants of FDI destinations by Japanese manufacturers using an econometric model. Included among the dependent variables was a trade friction indicator, as many Japanese FDIs were considered to avoid trade friction against the US and European countries. Following Deardorff and Stern (1990), Fukao and Cheng sought to adopt the price gap as a variable for tariff and non-tariff barriers. When they expanded the FDI host region to developing economies, however, collection of data for price gaps over many years proved difficult. Fukao and Cheng therefore substituted company survey results for a trade friction indicator. In an overseas operating plant, the ratio of motivation to investment, which are derived from business survey, was taken as an indicator of trade friction. Their research is important because trade friction is considered to be a reason for investment and should be taken into account.

Empirical research has been published in the present century on China's outward FDI. Wang et al. (2014) have pointed that China's outward direct investment has grown rapidly since 2004, and that there was little outward FDI in the 20th century (Note 1). In the last 10 years some papers have been published with the collection of statistical data. He and Lyles (2008), for example, conducted research on China's outward FDI to the US, focusing on political, cultural, marketing and technological aspects. Huang and Wang (2011) sought to consider the "China model". They conclude that outward FDI of China plays a role in strengthening Chinese industries more than expanding overseas production, by obtaining advanced technologies and securing a stable supply of commodities. In their work they divided outward FDI into investment in OECD economies and non-OECD economies. Advanced technologies are gained by directing outward FDI to the service sector in OECD economies, and commodities by directing it to non-OECD economies. Kolstad and Wiig (2012) explain that China's outward FDI to OECD economies tends to go to large markets, whereas outward FDI to non-OECD economies involves natural resources and poor institutions. Huang and Wang (2011) consider service industries in their examination of FDI from China to OECD countries, and Kolstad and Wiig (2012) consider manufacturing industries invested by China in OECD countries. Differences in China's FDI investment in OECD and non-OECD economies are discussed also by Hurst (2011). Hurst focused on state enterprises, and concluded that the FDI made by Chinese state enterprises in OECD economies aim to expand the market, whereas outward FDI to non-OECD economies is related to natural resources and potential trade relationships. Ramasamy et al. (2012) compared the motivation of outward investment by state enterprises with that by private enterprises. The difference was that outward FDI by 
state enterprises goes preferentially to the exploitation of natural resources and risky political environments, whereas outward FDI by private enterprises is attracted to markets.

These researches show that China's outward FDI can usefully be categorized by host country and type of industry. There is little research into China's outward investment to Asian economies. Kang and Jiang (2012) focused on China's outward FDI to East and Southeast Asian regions. They listed factors influencing FDI and proposed hypotheses, taking sub-factors into account. The factors are market, natural resource, efficiency, asset and institutions. One hypothesis is particularly notable, relating to the market openness of the host economy. What market is actually involved? If a trade barrier erected by an importing country is not between an investing country and another country, it is possible to invest in the third country so as to export from it. Kang and Jiang (2012) used this idea to introduce the variable of market openness, which is described by the ratio of an economy's exports to its total foreign trade. They conclude that this variable is significant and positive, meaning that such outward FDI is export-oriented.

\section{Trade Surplus and Accumulation of Foreign Reserve}

In the previous section we saw that there is no one simple reason for Chinese MNEs to invest abroad. Whether or not the main reason for outward FDI is capital endowment, the investing country must have enough foreign reserve. In this section we therefore review trends in China's external sector.

According to the balance of payment statistics, in the initial stage of economic reform in 1980s to mid-1990s, there was no large current account surplus in those years, and sometimes a deficit was recorded. The authorities in China prepared a system of special economic zones, and established several of these including Shenzhen, Shantou, Zhuhai and Xiamen in 1980. They introduced FDI inflow gradually. The foreign industries involved were labor intensive and export oriented. Stable FDI inflow began in the early 1990s and a current account surplus has been booked since the late 1990s (Figure 1). With current account surplus and FDI inflow which continued to exceed outflow, China's foreign reserve has increased greatly since the late 1990s. In particular, export growth has been remarkable. Exports on a US dollar basis continued to increase by more than 10\% each year, apart from the Asian Crisis (1997-2000) and the Global Financial Crisis (2009). The current account surplus was recorded at $10.1 \%$ of GDP in 2007. The resulting accumulation of foreign reserve exceeded 1 trillion US dollars in 2006, and Chinese foreign reserve exceeded that of Japan. By the end of 2014 it reached 3.9 trillion US dollars. This situation differed from Japan. Although Japan continued to record a current account surplus, outward FDI has exceeded inward FDI. China needs to manage its foreign reserve so as to avoid rapid appreciation of the Yuan. Hence China restricts FDI inflow except for high value added industries, and promotes outward FDI. In recent years its current account surplus has been stable, with an increase of imports. As exports remain huge, the current account will continue to be in surplus, and will be one of the forces driving outward FDI. 


\section{Macrothink}

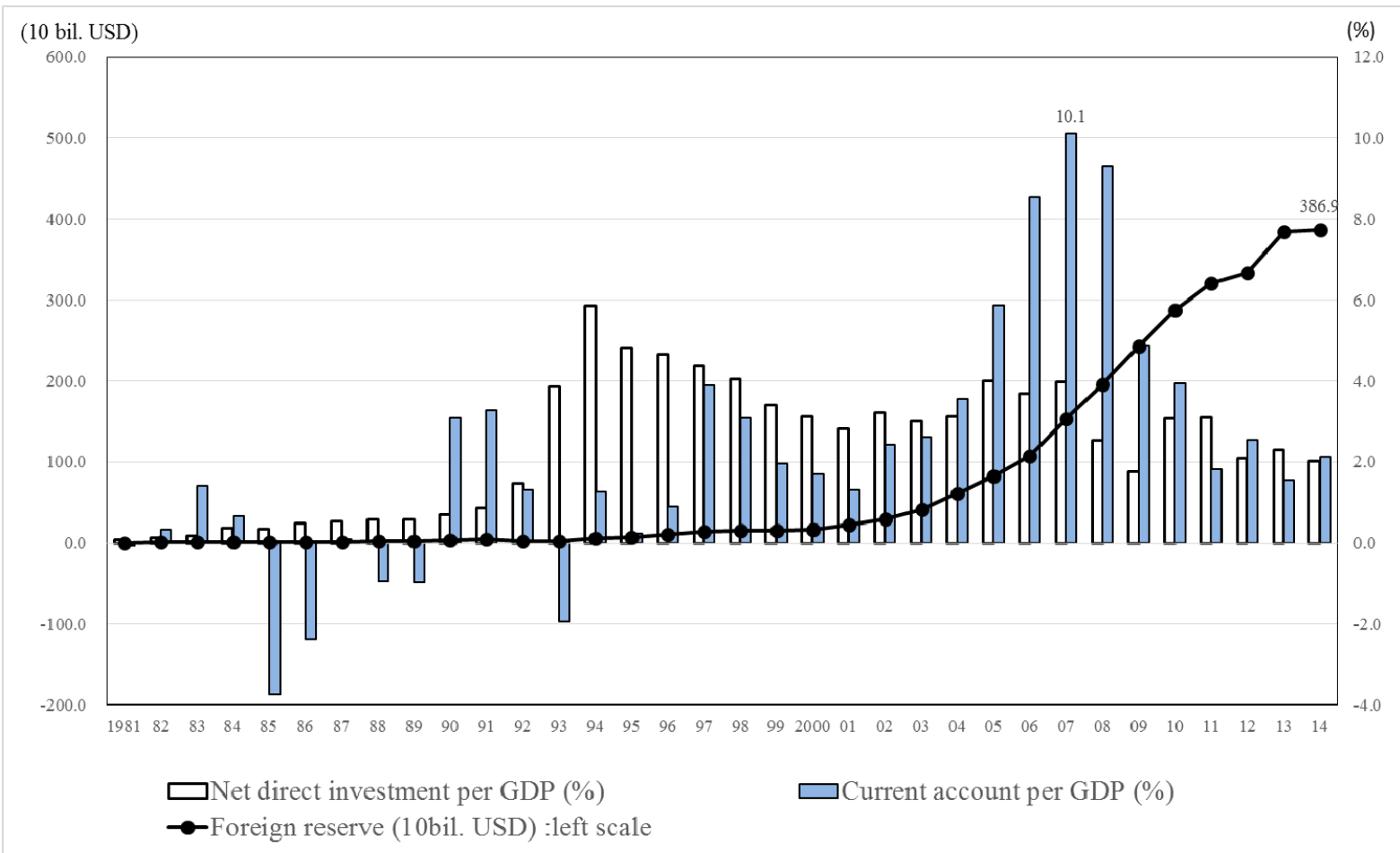

(Source) Asian Development Bank 'Key indicators'.

Figure 1. China's current account and foreign reserve

In analyzing external economic relations, we look at bilateral trades. According to UN Comtrade statistics, the total trade balance has been increasing (Figure 2). In 2014 the amount of surplus was as much as 384 billion US dollars. When the bilateral trade balance with the US and Japan is studied, contrasting features appear. The trade balance with Japan continues to be in deficit, but the trade balance with the US continues in surplus in increasing amounts, to 237 billion US dollars in 2014. This is the background of the trade friction between China and the US. Even with Japan, for which the export items are consumption goods, and the main items imported from Japan are machinery for equipment and intermediate goods, some trade friction issues exist. Meanwhile, China's trade balance with Thailand recorded a deficit in the period 1996 to 2014; in 2014 this deficit was 4 billion US dollars. There is no trade friction between Thailand and China. 


\section{Macrothink}

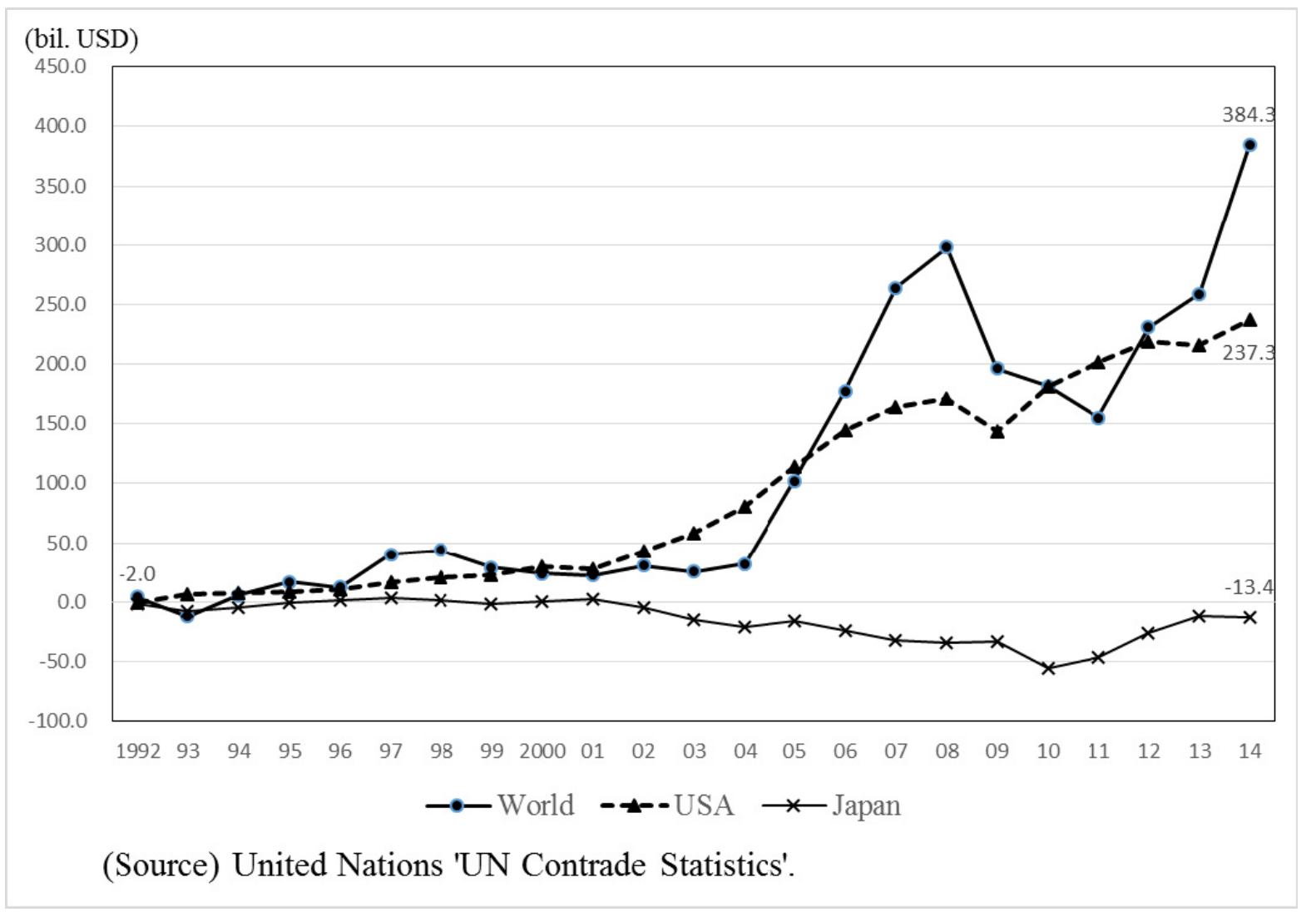

Figure 2. China's Trade Balance by Region

\section{Trend of China's outward FDI}

The macroeconomic situation explained in the previous section suggests that China's outward FDI will increase. There are, as discussed in section 2, many variables influencing the decision for Chinese MNEs to invest abroad. In this section we shall review outward FDI to Asia. Table 1 and Table 2 show China's annual outward FDI flow and stock. A significant portion of China's outward FDI has been directed to the Asian region, more than half to Hong Kong. Excluding FDI to Hong Kong, many FDI projects go to ASEAN countries, and the amount is increasing. FDI to ASEAN is larger than to the US, in both flow and stock. Of ASEAN countries, Singapore receives the most, followed by Indonesia, Lao PDR and Thailand. 
Table 1. China's outward FDI flow to Asian region (Unit: mil. USD)

\begin{tabular}{|c|c|c|c|c|c|c|c|c|c|c|c|}
\hline Host & 2004 & 2005 & 2006 & 2007 & 2008 & 2009 & 2010 & 2011 & 2012 & 2013 & 2014 \\
\hline World total & 5498 & 12261 & 17634 & 26506 & 55907 & 5629 & 68811 & 74654 & 87804 & 107844 & 123120 \\
\hline Asia & 3014 & 4484 & 7663 & 16593 & 43548 & 40408 & 44890 & 45494 & 64785 & 75604 & 84988 \\
\hline Hong Kong & 2628 & 3420 & 6931 & 13732 & 38640 & 35601 & 38505 & 35655 & 51238 & 62824 & 70867 \\
\hline ASEAN & 196 & 158 & 336 & 968 & 2484 & 2698 & 4405 & 5905 & 6100 & 7267 & 7809 \\
\hline Brunei & 0 & 2 & 0 & 1 & 2 & 6 & 17 & 20 & 1 & 9 & -3 \\
\hline Cambodia & 30 & 5 & 10 & 64 & 205 & 216 & 467 & 566 & 560 & 499 & 438 \\
\hline Indonesia & 62 & 12 & 57 & 99 & 174 & 226 & 201 & 592 & 1361 & 1563 & 1272 \\
\hline Lao PDR & 4 & 21 & 48 & 154 & 87 & 203 & 314 & 459 & 809 & 781 & 1027 \\
\hline Malaysia & 8 & 57 & 8 & -33 & 34 & 54 & 164 & 95 & 199 & 616 & 521 \\
\hline Myanmar & 4 & 12 & 13 & 92 & 233 & 377 & 876 & 218 & 749 & 475 & 343 \\
\hline Philippines & 0 & 5 & 9 & 5 & 34 & 40 & 244 & 267 & 75 & 54 & 225 \\
\hline Singapore & 48 & 20 & 132 & 398 & 1551 & 1414 & 1119 & 3269 & 1519 & 2033 & 2814 \\
\hline Thailand & 23 & 5 & 16 & 76 & 45 & 50 & 700 & 230 & 479 & 755 & 839 \\
\hline Vietnam & 17 & 21 & 44 & 111 & 120 & 112 & 305 & 189 & 349 & 481 & 333 \\
\hline Japan & 15 & 17 & 39 & 39 & 59 & 84 & 338 & 149 & 211 & 434 & 394 \\
\hline United States & 120 & 232 & 198 & 196 & 462 & 909 & 1308 & 1811 & 4048 & 3873 & 7596 \\
\hline
\end{tabular}

(Source) Ministry of Commerce of China 'Statistical bulletin of China's outward foreign direct investment'.

Table 2. China's outward FDI stock to Asian region (Unit: mil. USD)

\begin{tabular}{|c|c|c|c|c|c|c|c|c|c|c|c|}
\hline Host & 2004 & 2005 & 2006 & 2007 & 2008 & 2009 & 2010 & 2011 & 2012 & 2013 & 2014 \\
\hline World total & 44777 & 57206 & 7503 & 117911 & 183971 & 245755 & 317211 & 424781 & 531941 & 660478 & 882642 \\
\hline Asia & 33480 & 40954 & 47978 & 79218 & 131317 & 185547 & 228146 & 303435 & 364407 & 447408 & 600966 \\
\hline Hong Kong & 30393 & 36507 & 42270 & 68781 & 115845 & 164499 & 199056 & 261519 & 306372 & 377093 & 509920 \\
\hline ASEAN & 956 & 1256 & 1763 & 3953 & 6487 & 9571 & 14350 & 21462 & 28238 & 35668 & 47633 \\
\hline Brunei & 0 & 2 & 2 & 4 & 7 & 17 & 46 & 66 & 66 & 72 & 70 \\
\hline Cambodia & 90 & 77 & 104 & 168 & 391 & 633 & 1130 & 1757 & 2318 & 2849 & 3222 \\
\hline Indonesia & 122 & 141 & 226 & 679 & 543 & 799 & 1150 & 1688 & 3098 & 4657 & 6794 \\
\hline Lao PDR & 15 & 33 & 96 & 302 & 305 & 536 & 846 & 1276 & 1928 & 2771 & 4491 \\
\hline Malaysia & 123 & 187 & 197 & 275 & 361 & 480 & 709 & 798 & 1026 & 1668 & 1786 \\
\hline Myanmar & 20 & 24 & 163 & 262 & 500 & 930 & 1947 & 2182 & 3094 & 3570 & 3926 \\
\hline Philippines & 10 & 19 & 22 & 43 & 87 & 143 & 387 & 494 & 593 & 692 & 760 \\
\hline Singapore & 233 & 325 & 468 & 1444 & 3335 & 4857 & 6069 & 10603 & 12383 & 14751 & 20640 \\
\hline Thailand & 182 & 219 & 233 & 379 & 437 & 448 & 1080 & 1307 & 2127 & 2472 & 3079 \\
\hline Vietnam & 160 & 229 & 254 & 397 & 522 & 729 & 987 & 1291 & 1604 & 2167 & 2866 \\
\hline Japan & 139 & 151 & 224 & 558 & 510 & 693 & 1106 & 1366 & 1620 & 1898 & 2547 \\
\hline United States & 665 & 823 & 1238 & 1881 & 2390 & 3338 & 4874 & 8993 & 17080 & 21900 & 38011 \\
\hline
\end{tabular}

(Source) Ministry of Commerce of China 'Statistical bulletin of China's outward foreign direct investment'.

FDI to Thailand is not particularly large, but has been increasing in recent years, and the 
amount is more than that to Japan. More than half of China's outward FDI to Thailand is related to manufacturing. Table 3 shows China's FDI quantitatively by industry directed to Thailand and its neighboring countries. In Thailand, as much as $58.7 \%$ of FDIs are in the manufacturing industry. In Indonesia and Lao PDR a relatively high proportion of investment is in natural resource exploitation, such as agriculture and mining.

Table 3. Number of outward FDI by industry at home

\begin{tabular}{lllllll}
\hline & & Agriculture & Mining & Manufacture & Service & Total \\
\hline Indonesia & Number & 33 & 61 & 226 & 209 & 529 \\
& (Ratio) & $(6.2)$ & $(11.5)$ & $(42.7)$ & $(39.5)$ & $(100.0)$ \\
\hline Lao PDR & Number & 46 & 74 & 132 & 274 & 526 \\
& (Ratio) & $(8.7)$ & $(14.1)$ & $(25.1)$ & $(52.1)$ & $(100.0)$ \\
\hline Malaysia & Number & 5 & 12 & 148 & 127 & 292 \\
& (Ratio) & $(1.7)$ & $(4.1)$ & $(50.7)$ & $(43.5)$ & $(100.0)$ \\
Thailand & Number & 13 & 11 & 222 & 132 & 378 \\
& (Ratio) & $(3.4)$ & $(2.9)$ & $(58.7)$ & $(34.9)$ & $(100.0)$ \\
\hline
\end{tabular}

(Source) Marukawa et al. (ed.) (2014).

According to IMF statistics, Thailand's per capita GDP in 2013 and 2014 was 6148 and 5889 US dollars. For China the figures were 6995 and 7625 US dollars, slightly greater; the gap is not such as to increase the FDI significantly. The smaller Thai population limits the market for internal consumption, but measures to promote investment provide a motivation for FDIs. The Board of Investment of Thailand (BOI), which is chaired by the Prime Minister, was established in 1977 to promote FDI inflow. It has enacted corporate tax reduction, exemption of tariffs on material for export, and other measures (Note 2). At the same time, infrastructure was constructed. Industrial agglomeration in Thailand is a further advantage to investors in manufacturing. Prior to economic reform in China, Thailand commenced industrialization and promoted export-oriented industries, from the 1980s. Industrial parks were built on the eastern seaboard area, in which many FDI projects enjoy the greatest promotion privileges. The main investors in Thailand are Japanese MNEs, but the system is open to investors from other countries. A further reason for ready FDI inflow to Thailand is the openness of the external market, and this is discussed in the next section.

\section{Trade friction and China's outward FDI to Thailand}

In this section, we discuss trade friction involving China, as compared to Thailand. Thailand is open to the US and the EU for free trade. We then discuss the characteristics of FDI projects in Thailand from the viewpoint of avoiding trade friction. A substantial proportion of FDI projects involve products facing trade friction from China. We discuss the export situation of these items. 


\subsection{Openness of Thailand}

Kang and Jiang (2012) stated that market openness of the host country is an important factor influencing investment by Chinese MNEs. Under Thailand's development policies, the trade and investment system has been liberalized and export-oriented industrialization has been promoted (Note 3). Trade liberalization generally includes reductions in tariffs, and is often followed by the abolition of export subsidies. This has generated good economic relationships with developed countries. In particular, the US made a Trade and Investment Framework Agreement (TIFA) with Thailand in October 2002, earlier than with Indonesia (September 2004) or Malaysia (May 2004). Regarding the generalized system of preferences (GSP), the US grants GSP to Thailand for some items, although lower income countries such as Vietnam and Lao PDR are not granted (Table 4). China has not shared in a TIFA with the US and is not granted GSP.

Table 4. Trade agreements of the US with ASEAN countries

\begin{tabular}{lll}
\hline & Agreed date of TIFA & GSP \\
\hline Brunei & - & - \\
Cambodia & Jul. 2006 & granted \\
Indonesia & Sep. 2004 & granted \\
Lao PDR & Feb. 2016 & - \\
Malaysia & May 2004 & - \\
Myanmar & May 2013 & - \\
Philippines & Nov. 1989 & granted \\
Singapore & (FTA: in 2004) & - \\
Thailand & Oct. 2002 & granted \\
Vietnam & Jul.2007 & - \\
\hline
\end{tabular}

(Source) Website of the United States Trade Representative (USTR).

(Note) TIFA with China is not agreed. GSP is not granted to China.

There is therefore likely to be much less trade friction between Thailand and developed economies than in the case of China. When MNEs in China consider investing in the Asian region, Thailand is a leading candidate. Tables 5 shows the number of products about which the US or EU has complained of dumping by China and Thailand, triggering WTO investigations. The WTO website shows that complaints of dumping 180 items of export from China were made by the US during 1995 to 2014, and 39 items from Thailand. Of these 39 items, 30 items were in common with China; therefore only 9 items complained of as being dumped are Thai-specific. The situation with the EU is similar. A total of 163 items of export from China attracted complaints, and 31 items from Thailand. Of those 31 items, 22 items were in common with China and only 9 items were specific to Thailand.

We conclude that developed countries regard the external economic policies of Thailand as liberal, relative to China (Note 4). There is good reason for Chinese MNEs to invest in 
Thailand, to prevent trade friction between China and developed countries.

Table 5. Number of disputed items by anti-dumping raised by the US and the EU

\begin{tabular}{lrrr}
\hline \multicolumn{2}{c}{ Both China and Thailand } & To China & \multicolumn{2}{c}{ To Thailand } \\
\hline By US & 30 & 150 & 9 \\
By EU & 22 & 141 & 9 \\
\hline (Source) Website of WTO. & & &
\end{tabular}

\subsection{China's outward FDI projects to Thailand}

BOI statistics facilitate our studies of the characteristics of outward FDI. When the BOI grants privileges to investors, it has released, since 2007, detailed information about individual project which it approved. A total of 8,679 projects have been approved by the BOI from 2007 to 2014. Of these, there were 240 investment projects from China. (The largest investor in Thailand is Japan.) We checked the product items from the BOI information against the list of trade friction items. When a product was not clear from the BOI list, we sought to confirm it from the firm's website. The resulting classification of BOI approved projects is shown in Table 6 . We found 94 projects that produce items involved in Chinese trade friction, corresponding to $39.2 \%$ of total Chinese FDIs by number of projects. We found some items for which Thailand also encounters trade friction. Some items from China attracted complaints by both the US and the EU, but from Thailand those items were complained of by only one of the two. Another possibility is that the imposed additional tariff rate or period was different for China and Thailand. Of the remaining 146 projects, 35 projects $(14.6 \%)$ are unclear, and 111 projects $(46.3 \%)$ do not produce trade friction items. The conclusion is that between $39.2 \%$ and $53.8 \%$ (Note 5) of China's FDIs to Thailand produce trade friction items. This supports the hypothesis that trade openness of Thailand with developed countries is a determinant of China's outward FDI.

To verify the hypothesis, we collected additional information about whether such projects are investments to avoid trade friction with China's trade counterparts. As the BOI information records the name of both subsidiary in Thailand and mother company in China as investor, the authors surveyed the website of such projects-related articles (Note 6). As a result, of the 94 projects, we found 12 whose website, or whose mother company's website in China, actually mentioned the avoidance of trade friction or anti-dumping measures, or whose spokesman had made similar comments to news media (Note 7). This information is summarized in Table 7. We conclude that a substantial amount of China's outward FDI to Thailand is conducted in order to avoid trade friction. 


\section{Macrothink}

Table 6. China's FDI projects related to trade friction

\begin{tabular}{ccccc}
\hline Approved year & Specified & Not clear & Not related & Total \\
\hline 2007 & 9 & 4 & 13 & 26 \\
2008 & 7 & 5 & 15 & 27 \\
2009 & 1 & 4 & 4 & 15 \\
2010 & 11 & 1 & 17 & 29 \\
2011 & 15 & 3 & 20 & 38 \\
2012 & 14 & 9 & 12 & 35 \\
2013 & 12 & 2 & 16 & 30 \\
2014 & 19 & 7 & 14 & 40 \\
Total & 94 & 35 & 111 & 240 \\
Share (\%) & 39.2 & 14.6 & 46.3 & 100.0 \\
\hline
\end{tabular}

(Note) Specified: Project to produce items which China has trade friction with some country/economy. Not clear: To produce trade friction related items without clear evidence. Not related: Project to produce other items.

Table 7. China's investment projects to avoid trade friction

\begin{tabular}{|c|c|c|}
\hline Name of company in Thailand & Product item & Information source \\
\hline WSP Pipe Co., Ltd. & Seamless steel pipe & China Hangzhou Daily (Oct. 10, 2010) \\
\hline $\begin{array}{l}\text { Asia Composite Materials (Thailand) } \\
\text { Co. Ltd. }\end{array}$ & $\begin{array}{l}\text { Fiberglass chopped } \\
\text { strand mat; fiberglass } \\
\text { woven roving }\end{array}$ & $\begin{array}{l}\text { Website of Sichuan Weibo New Material } \\
\text { Group Co., Ltd }\end{array}$ \\
\hline Sunrise Candles Co. Ltd. & Candle product & Website of Sunrise Candles Co. Ltd. \\
\hline Bosun Tools （Thailand） Co. Ltd. & Saw blade & Website of Bosun Tools Co., Ltd. \\
\hline $\begin{array}{l}\text { Gang Yan Diamond Tools (Thailand) } \\
\text { Co. Ltd. }\end{array}$ & $\begin{array}{l}\text { Saw blade; saw blade } \\
\text { repairing }\end{array}$ & Website of Aetna Technology Co., Ltd. \\
\hline HXF (Thailand) Co., Ltd. & Metal products & $\begin{array}{l}\text { Website of China Black Whirlwind Saw } \\
\text { Industry Co., Ltd. }\end{array}$ \\
\hline KingThai Diamond Tools Co. Ltd. & Machine components & $\begin{array}{l}\text { Yanzhao Metropolis Newspaper (No. 9, } \\
\text { May, 2014) }\end{array}$ \\
\hline Mei Lan (Thailand) Co., Ltd. & Steel tube & $\begin{array}{l}\text { Website of China Wuhan seamless } \\
\text { Petroleum Steel Pipe Co., Ltd. }\end{array}$ \\
\hline Zhongce Rubber (Thailand) Co., Ltd. & $\begin{array}{l}\text { Compounded rubber; } \\
\text { radial tire }\end{array}$ & $\begin{array}{l}\text { Website of Hangzhou China Strategic } \\
\text { Holdings Ltd. }\end{array}$ \\
\hline $\begin{array}{l}\text { Dunan Metals (Thailand) Co., Ltd. } \\
\text { (A) }\end{array}$ & Air conditioner parts & $\begin{array}{l}\text { Website of Zhejiang shield the artificial } \\
\text { environment Equipment Inc. }\end{array}$ \\
\hline $\begin{array}{l}\text { Dunan Metals (Thailand) Co., Ltd. } \\
\text { (B) }\end{array}$ & Air conditioner parts & \\
\hline Yuli Plastic (Thailand) Co., Ltd. & PVC tarpaulins & Jiaxing Daily (Apr. 17, 2014) \\
\hline
\end{tabular}

(Source) BOI statistics, each website mentioned in the column.

(Note) Content of "Product item" is from the list of BOI.

\section{Structural Change in Trade of China and Thailand}

A further hypothesis of interest about China's outward FDI to Thailand is whether such 
investments increase the export from Thailand of such items and concomitantly reduce their export from China. We picked up the codes of trade items which attracted complaints from the US and were produced by FDI directed to Thailand, using the WTO's anti-dumping information. We summed each year's export volume from Thailand and from China to the US and to the rest of the world. The results of aggregated export figures were surprising. Exports from China continued to increase, whereas exports from Thailand have decreased in recent years (Table 8).

Table 8. Exports of items in friction with US and invested to Thailand

\begin{tabular}{|c|c|c|c|c|}
\hline & \multicolumn{2}{|c|}{ Export of China } & \multicolumn{2}{|c|}{ Export of Thailand } \\
\hline & To US & To World & To US & To World \\
\hline 1992 & 450 & 1896 & 651 & 2166 \\
\hline 1993 & 429 & 1887 & 803 & 2602 \\
\hline 1994 & 634 & 2725 & 1063 & 3289 \\
\hline 1995 & 944 & 3921 & 1012 & 3803 \\
\hline 1996 & 823 & 4051 & 1017 & 3684 \\
\hline 1997 & 934 & 4761 & 1107 & 3588 \\
\hline 1998 & 1388 & 5571 & 1170 & 3494 \\
\hline 1999 & 1760 & 6528 & 1340 & 3814 \\
\hline 2000 & 2502 & 9289 & 1732 & 4632 \\
\hline 2001 & 2832 & 10107 & 1438 & 4128 \\
\hline 2002 & 3943 & 12767 & 1318 & 3856 \\
\hline 2003 & 5789 & 18309 & 1387 & 4342 \\
\hline 2004 & 8382 & 26868 & 1414 & 5136 \\
\hline 2005 & 10936 & 35727 & 1617 & 5179 \\
\hline 2006 & 14288 & 48239 & 2094 & 7280 \\
\hline 2007 & 17476 & 71655 & 1919 & 8297 \\
\hline 2008 & 20622 & 92925 & 2046 & 9455 \\
\hline 2009 & 12617 & 64995 & 1914 & 8155 \\
\hline 2010 & 18711 & 105207 & 2365 & 10637 \\
\hline 2011 & 24075 & 133563 & 2739 & 12166 \\
\hline 2012 & 24703 & 127985 & 2008 & 11800 \\
\hline 2013 & 24835 & 129747 & 1796 & 11321 \\
\hline 2014 & 28766 & 142839 & 1732 & 11278 \\
\hline 2015 & 27469 & 139385 & 1730 & 10401 \\
\hline
\end{tabular}

(Source) UN Comtrade statistics.

(Note) Export items are those were issued by the US and EU.

Exports of Thailand of these items from Thailand peaked in 2011 and decreased thereafter. Exports of these items from Thailand were more than those from China until 1997. We suggest that industries producing these items have generally been losing competitiveness in 
Thailand. This could be because China has been catching up with Thailand in industrialization. Such a situation may influence the decisions of Chinese MNEs whether to enter into production in Thailand. Also, exports from China continue. Even with anti-dumping tariffs, many firms operating in China maintain price competitiveness. This may increase the countermeasures by the US, which will be an extra burden for less competent firms. Some may decide to move out to Thailand despite the extra costs. The amount of volume of exports added by such firms does not cancel the decreasing trend in Thailand. At the same time, if Thailand has a large amount of declining industries, Chinese firms may acquire plants or equipment easily from Thai enterprises. This would be another advantage of investing in Thailand.

\section{Conclusion}

In this paper, the authors analyzed the determinants of China's outward FDI, focusing on the trade friction. Firstly, the advancements of analysis on FDI determinants were surveyed through literature review. There, factor of trade friction started to be analyzed with starting of investments from Japan and other Asian nations. In particular, the authors noted Kang and Jiang (2012) as they formulated an econometric model about China's outward FDI to Eastern and Southeastern Asia. They clarified that the openness of market in FDI recipient was a significant determinant.

From such literatures, the authors put the first purpose of this paper to verify the validity of this discussion by collecting information on individual investment behaviors rather than by a similar econometric analysis. We could achieve the successful result in this point. Thailand was selected as a research country, because the weight of China's FDI in manufacturing sector is very high to Thailand and Thailand has faced less trade friction with western countries comparing to China. If any portion of China's FDI aims to avoid trade friction, Thailand is expected to be a good investment destination.

The authors found that the BOI releases information of the individual investment project when it approves the privilege for investment promotion, and we collected the information of investment projects from China. The information includes the name of investing company, product items and so on. It made us possible to find the projects which produce the trade friction related items in China. We clarified that 94 projects, which are around $40 \%$ of total China's investment projects during 2007 to 2014, produce the trade friction related items. This finding will not contradict the idea that some Chinese companies invested in Thailand to avoid trade friction. In order to support the idea, further information of such 94 projects were surveyed. The authors could find 12 projects to give comments either their own website or media interview that they invested in Thailand to avoid trade friction. Taken these findings together, we can confirm that a substantial portion of China's outward FDI to Thailand was aimed to avoid trade friction.

On the other hand, another purpose to verify the hypothesis that exports of such items from Thailand would increase while those from China would decrease, cannot be supported. Our research resulted in opposite side, namely, to decrease the export from Thailand and to continue increasing of exports from China. The fact that exports from Thailand had already 
started to decrease before China's FDI in such items came to Thailand, may mean that such industry field did not match the field for Government of Thailand to promote at that time. However the authors should admit that consideration is not enough in this paper, as the situation is different from our hypothesis. The research including Thai local firms in this area should be conducted in the future.

\section{References}

Asian Development Bank (ADB)-ADB Key Indicators for Asia and the Pacific. Retrieved from July 30, 2016, http://www.adb.org/publications/series/key-indicatorsfor-asia-and-the-pacific

Board of Investment of Thailand (BOI)-BOI statistics. Retrieved August 30, 2016, from http://www.boi.go.th/index.php?page=statistics_foreign_direct_investment

Bosun Tools Co., Ltd.. Retrieved January 10, 2016, from http://www.cninfo.com.cn/finalpage/2012-04-10/60804599.PDF

China Black Whirlwind Saw Industry Co., Ltd. Retrieved January 10, 2016 from http://www.csrc.gov.cn/pub/zjhpublic/G00306202/201412/P020141226590769060050.pdf (In Chinese)

China Hangzhou Daily. Retrieved January 10, 2016, from http://hzdaily.hangzhou.com.cn/hzrb/html/2010-12/01/content_978611.htm (In Chinese)

China Wuhan seamless Petroleum Steel Pipe Co., Ltd. Retrieved January 10, 2016, from http://doc.mbalib.com/view/19a814308940efd7362f4378dccc6d62.html (In Chinese)

Deardorff, A. V., \& Stern, R. M. (1990). Computational analysis of global trading arrangements. Ann Arbor, MI: University of Michigan Press.

Fukao, K., \& Cheng, X. (1996). Determinants of direction of foreign direct investment: Empirical study on Japanese manufactures. Financial Review, 38, 1-31 (In Japanese).

Grubert, H., \& Mutti, J. (1991). Taxes, tariffs and transfer pricing in multinational corporate decision making. The Review of Economics and Statistics, 73(2), 285-293. https://doi.org/10.2307/2109519

Hangzhou China Strategic Holdings Ltd. Retrieved January 10, 2016, from http://www.chaoyang.com/

He, W., \& Lyles, M. A. (2008). China's outward foreign direct investment. Business Horizons, 51, 485-491. https://doi.org/10.1016/j.bushor.2008.06.006

Huang, Y., \& Wang, B. (2011). Chinese outward direct investment: Is there a China model? China \& World Economy, 19(4), 1-21. https://doi.org/10.1111/j.1749-124X.2011.01254.x

Hurst, L. (2011). Comparative analysis of the determinants of China's state-owned outward direct investment in OECD and non-OECD countries. China \& World Economy, 19(4), 74-91. https://doi.org/10.1111/j.1749-124X.2011.01251.x 
Hymer, S. H. (1960). The international operations of national firms: A study of direct foreign investment. Cambridge, Mass: MIT Press.

Kang, Y., \& Jiang F. (2012). FDI location choice of Chinese multinationals in East and Southeast Asia: Traditional economic factors and institutional perspective. Journal of World Business, 47, 45-53. https://doi.org/10.1016/j.jwb.2010.10.019

Kindleberger, C. P. (1969). American business abroad: Six lectures on direct investment. Yale University Press. https://doi.org/10.1002/tie.5060110207

Kohpaiboon, A. (2003). Foreign trade regimes and the FDI-growth Nexus: A case study of Thailand. The Journal of Development Studies, 40(2), 55-69. https://doi.org/10.1080/00220380412331293767

Kolstad, I., \& Wiig, A. (2012). What determines Chinese outward FDI. Journal of World Business, 47, 26-34. https://doi.org/10.1016/j.jwb.2010.10.017

Komiya, R., \& Amano, A. (1972). International Economics. Iwanami Shoten. (In Japanese)

MacDougall, G. D. A. (1960). The benefits and costs of private investment from abroad: A theoretical approach. Economic Record, Special Issue, March, Reprinted in R. E. Cavas and H.G Johnson (ed.), Readings in International Economics. 1968, London: George Allen and Unwin. https://doi.org/10.1111/j.1475-4932.1960.tb00491.x

Marukawa, T., Ito, A., \& Zhang, Y. (ed.) (2014). China's Outward Foreign Direct Investment Data. Institute of Social Science, University of Tokyo ISS Contemporary Chinese Research Series No.15.

Ministry of Commerce of the People's Republic of China, National Bureau of Statistics of the People's Republic of China and State Administration of Foreign Exchange. (2010-2015). Statistical Bulletin of China's Outward Foreign Direct investment. China Statistics Press.

Ramasamy, B., Yeung, M., \& Laforet, S. (2012). China's outward foreign direct investment: Location choice and firm ownership. Journal of World Business, 47, 17-25. https://doi.org/10.1016/j.jwb.2010.10.016

Sichuan Weibo New Material Group Co., Ltd. Retrieved January 10, 2016, from http://www.chinaweibo.cc/news/Article/ShowArticle.asp?ArticleID=65064 (In Chinese)

Sunrise Candles Co. Ltd. Retrieved January 10, 2016, from http://th104840346.en.forbuyers.com/about/ (In Chinese)

UN Comtrade Statistics. Retrieved August 29, 2016, from http:/comtrade.un.org/data/

United States Trade Representative (USTR)-USTR Trade \& Investment Framework Agreements. Retrieved August 25, 2016, from https://ustr.gov/trade-agreements/trade-investment-framework-agreements

Urata, S., \& Yokota, K. (1994). Trade liberalization and productivity growth in Thailand. The Developing Economies, 32(4), 444-459. https://doi.org/10.1111/j.1746-1049.1994.tb01049.x 


\section{Macrothink}

Wang, B., Mao, R., \& Gou, Q. (2014). Overseas impacts of China's outward direct investment. Asian Economic Policy Review, 9, 227-249. https://doi.org/10.1111/aepr.12065

Wheeler, D., \& Mody, A. (1992). International investment location decisions. Journal of International Economics, 33, 57-76. https://doi.org/10.1016/0022-1996(92)90050-T

World Trade Organization (WTO) - WTO anti-dumping. Retrieved January 10, 2016 from https://www.wto.org/english/tratop_e/adp_e/adp_e.htm

Zhejiang shield the artificial environment Equipment Inc. Retrieved January 10, 2016, from http://www.cninfo.com.cn/cninfo-new/disclosure/szse_sme/bulletin_detail/true/51902917?an nounceTime $=2009-04-29 \% 2007: 30$ (In Chinese)

\section{Notes}

Note 1 . The economic situation external to China will be discussed in the next section.

Note 2. The government of Thailand announced an amendment of investment promotion measures in 2013. Fewer industries would be promoted. This may influence future FDI inflow to Thailand.

Note 3. According to Urata and Yokota (1994) and Kohpaiboon (2003), the government of Thailand promoted trade liberalization in the 1980s with a reduction in tariff rates. This liberalization was essentially completed in the 1990s.

Note 4. The coup d'etats in Thailand in 2006 and 2014 influenced free trade agreement negotiations between Thailand and the US (in 2006) and between Thailand and the EU (in 2014). Free trade negotiations have a political aspect, but only a small impact on economic affairs.

Note 5. Upon adding the 35 unclear projects to 94 projects we obtain 129 projects, or $53.8 \%$ of the total of 240 projects.

Note 6. For example, as for the first company of the Table 7, "WSP Pipe Co. Ltd.," the responsible person of the plant in Thailand explained to the China Hangzhou Daily that they had invested in Thailand because both the US and EU would not raise the anti-damping issue, on October 10th 2010. As for the second company of that table, "Asia Composite Material (Thailand)", its mother company in China announced that the subsidiary in Thailand was expected to generate additional profit as much as 100 million Yuan in yearly basis because it could avoid trade friction against the EU.

Note 7. Since two projects were from investments by the same company, the number of companies is 11 . 


\section{Macrothink

\section{Copyright Disclaimer}

Copyright for this article is retained by the author(s), with first publication rights granted to the journal.

This is an open-access article distributed under the terms and conditions of the Creative Commons Attribution license (http://creativecommons.org/licenses/by/4.0/). 